CURRENT RESEARCH JOURNAL OF PHILOLOGICAL SCIENCES 2(7): 05-09,

May 2021 DOI: https://doi.org/10.37547/philological-crjps-02-07-02

ISSN 2767-3758

(C)2021 Master Journals

Crossref do) 81 Google

Accepted09thJuly, 2021 \& Published 14thJuly, 2021

\title{
ABOUT PARAPHRASES AND NICKNAMES IN THE NOVEL OF “CHOLIKUSHI”
}

\section{Muazzama Foziliya}

Student Faculty Of Turkic Studies Tashkent State University Of Oriental Studies, Uzbekistan

\section{ABSTRACT}

This article discusses the phenomenon of renaming events and individuals by describing their characteristics, not by their names. It has also been suggested that people have nicknames that refer to their strengths and weaknesses. Paraphrases are then used to describe speech as a means of stylistics. Paraphrases are said to be renaming by describing objects, events, and types, and their types are listed according to their structure. Paraphrases have been noted to serve not only to enrich charm, imagery, and speech, but also to reinforce its content. The lexical unit of the nickname, in turn, has four different meanings. At the same time, Rashod Nuri Guntekin connects the whole system of events in the novel "Cholikushi" with certain paraphrases and divides them into three parts: "Farida - Cholikushi", "Farida - Silkworm", "Farida Gulbashakar". It is said that the events of the work are developed by the author around these paraphrases, and the author creates original tools. It is emphasized that each paraphrase and nickname in the work is a unique invention of the author, which is skillfully used in the novel as a methodological tool. It is noted that Rashod Nuri Guntekin's novel "Cholikushi" effectively used paraphrases and nicknames. The author is in his work "Çalıkuşu"( Cholikushi), "İpekböceği"(Silkworm), "Gülbeşeker"(Gulbashakar), "Evliya parmaklığı"(Saint's paw), "Küçük"(Small) paraphrases, "Sakallı Amca"(Bearded Uncle), "Gourde"(Gourd), "San çıanıı"(Yellow scorpion), "Ayı Dayı"( Bear wrestler), "Sarı zalim"(yellow cruel), "Sarı mahluk"(yellow monster), "Düldül"(Duldul), "Odabaşı"(Captain), "Sevgili ayıcıklarım"(dear bears) emphasis was placed on the skillful use of nicknames in their place, and analyzed through examples. In the conclusion, the main part of the nicknames are Turkish words, some of which are Persian (gül, dayı) and Arabic (zalim, mahluk) words, only one nickname is French (gourde) which was used to convey the spirit of the time.

KEYWORDS: - Renaming, nickname, aesthetic relation, paraphrase, stylistic means, types of paraphrases, nickname and its four different meanings, Rashod Nuri Guntekin, novel "Cholikushi".

\section{INTRODUCTION}

All over the world, including the Turkic peoples, there is a phenomenon of renaming events and individuals not by their own names, but by describing their characteristics. There is also the case of calling people by a nickname that refers to their positive and negative states. We know that any image or nickname given to people has an aesthetic value.

Paraphrase (Greek "paraphrasis"- figurative expression, image). The thing is to describe events not in their own name, but in a figurative way based on their characteristics; such an expression. For example, the queen of the field (corn), the blue fire (gas) [21.80]. Paraphrases, as a stylistic tool, give the speech an uplifting, figurative. Enriches the vocabulary according to 
CURRENT RESEARCH JOURNAL OF PHILOLOGICAL SCIENCES 2(7): 05-09,

May 2021 DOI: https://doi.org/10.37547/philological-crjps-02-07-02

ISSN 2767-3758

(C)2021 Master Journals

\section{Crossref do) 8 Google}

Accepted09thJuly, 2021 \& Published 14thJuly, 2021

the requirements of the society. Allows you to avoid repetitions, repetitions during the speech process. Encourages the speaker to speak and the listener to think philosophically. Linguist Ikhtiyor Umirov, who has studied Uzbek paraphrases, described these methodological tools as follows. A paraphrase is the renaming of an object, an event, or an event, not by its name, but by describing its characteristics. Including white gold - cotton, intellectuals - scientists, green season - spring and others [22.5]. Paraphrases can be divided into the following types, depending on how many words they consist of: 1) one word. For example: intelligent (educated), astronaut (astronaut), weak (woman); 2) consists of two words. For example: silver fiber (cocoon), Greek rum (Yildirim Boyazid); 3) consists of three words. For example: Sultan of the Gazelle (Alisher Navoi), Singer of Freedom and Liberty (Abdulhamid Cholpon); 4) consists of four words. For example: Founder of the Uzbek National Novel (Abdulla Qodiriy), Founder of the Uzbek National Variety (Botir Zokirov).

\section{THE MAIN FINDINGS AND RESULTS}

Paraphrases serve not only to enrich charm, imagery, and speech, but also to reinforce its content. It is also used to expose the evils that hinder society's progress and to call for action. Therefore, paraphrases are an important means of speech in describing, exaggerating, interpreting, and supplementing important features of an object that do not appear in its own name.

Nickname (Arabic "second name", "nickname", "nickname"). 1. An additional name given to a person as a joke or ridicule, depending on a feature. It is also a name that has been changed for a purpose or necessity. For example: He got the nickname "Little" ... jokingly (H.N.). I have been running away from the hands of the Emir's people for twenty-five years, changing my place and going by the nickname "Memory", so you thought I was dead (Aini). 2. Pen-name. For example: Muhammad Aminkhoja is now known as Muqimi. I also want to introduce you to the public with a nickname! The teacher said that your nickname should be Mawlawi (S.A.). 3. Surname. 4. Name given to animals. For example: The milk of two heifers, Chalma and Medunka, will be tested [23.492] (N.M.). It is clear from this commentary that the nickname has four different meanings in the lexical unit. Writers use these meanings of the word in their works. This serves to further enhance the national appeal of each language.

Rashod Nuri Guntekin conditionally divided the whole system of events in the novel "Cholikushi" into three parts, connecting them with certain paraphrases. These are: "Farida - Cholikushi" (pages 8-249), "Farida - Silkworm" (pages 250266), "Farida - Gulbashakar" (pages 267-404). The events in the work are developed around these paraphrases. The author uses all his skills to create original aesthetics. The image begins with the adventures of a chittushi - chittak, released in the title of the novel. The little girl, who is silent but spoils the world, is deeply ingrained in the reader's heart and evokes a positive attitude towards him. Each paraphrase and nickname in the work is a unique discovery of the writer. They are skillfully used in the novel as a methodological tool:

1. "Çalıkuşu"(Cholikushi). The name is given to Farida because of her restlessness, joy, fearlessness and zeal. For example:1) Firsat buldukça oraya tırmandığımı ve tehditlere kulak asmadan teneffüs sonuna kadar daldan dala atladığımı gören muallim bir gün, "Bu çocuk insan değil, çalıkuşu!" diye bağırmıștı (P. 23). (My teacher, who saw me clinging to it until the time came, jumping from branch to branch without listening to the threats, said, "This man is not a child, she is a Cholikushi"). 2) İște o 
CURRENT RESEARCH JOURNAL OF PHILOLOGICAL SCIENCES 2(7): 05-09,

May 2021 DOI: https://doi.org/10.37547/philological-crjps-02-07-02

ISSN 2767-3758

(C)2021 Master Journals

\section{Crossref do) 8 Google}

Accepted09thJuly, 2021 \& Published 14thJuly, 2021

günden sonra adım unutulmuş ve herkes beni "Çalıkuşu" diye çağırmaya başlamıştı. Bilmem nasıl, sonradan bu isim, aile arasında aldı yürüdü ve Feride adı bayram elbiseleri gibi pek sayılı günlerde kullanılan resmi bir ad olup kaldı (P. 23). So from that day on, my real name was forgotten and everyone called me Cholikushi. I know how the name was later passed on to our family, and Farida has become an official horse that is rarely used as a holiday dress.

2. "İpekböceği”(Silkworm). The name is given to Farida for her beauty, graceful nature, composure, knowledge and culture of behavior. For example: - "İpekböceği” benim yeni ismim. Çalıkuşu bitti. Şimdi “İpekböceği” çıktı (P. 250). ("Silkworm" is my new nickname. Cholikushi is over. Now "Silk Worm" is out.)

3. "Gülbeşeker"(Gulbashakar). The name is given to Farida's uniquely bright complexion, healthy nature, beautiful demeanor and demeanor. For example: - Zavallı Feride'ciğim, sen ne kadar safsın! Gülbeşeker, Ç... erkeklerinin, bu güzel rengin için sana koydukları isim (P. 274-275). (Farida, how simple you are! Ch ... men named you Gulbashakar for this beautiful color!)

4. "Evliya parmaklığı"(Saint's paw). The name is given because Farida's hand is always sore. For example: Bu sakallı amca, benim ellerime "Evliya parmaklığı" derdi (P. 20). (That bearded uncle used to call my hands "Saint's paw".)

5. "Küçük"(Little). The nickname was given by a military doctor to a foreigner and a stubborn girl who was as close as her own child. For example: Fakat, tam bu dakikada, yüzünü çevirmişti. Birdenbire: - Vay küçük yine mi sen? diye bağırdı (323). (But at that moment he turned to us and suddenly said: - Wow, little one, are you?! He sent. )

6. "Sakallı Amca" (Bearded uncle). The nickname was given to the man because of his long beard, intelligence and ingenuity. For example: Bütün çocukların "Sakallı Amca" diye çağırdıkları tuhaf bir akrabamız vardı (P. 20). (We had a cousin with a strange nature that all the kids would call a "bearded uncle").

7. “Gourde”(Gourd) (asmakabağı, sukabağı, balkabağ 1 ). The nickname was given secretly because of Farida's disregard for her appearance and emotions, according to a brief summary of her peers. For example:- Ben değil herkes öyle düşünüyor... Sevgi işinde Çallkuşu bir hakiki gourde'dur, diyorlar. Türkçesini pek iyi bilmiyordum ama, gourde Fransizcada asmakabağı, sukabağı, balkabağı gibi bir manaya gelirdi (46-bet). - (Not only me, but everyone thinks so ... In the chapter on love, Cholikushi is called a real gourd. I don't know Turkish very well, but in French gourd means hang, watermelon, pumpkin).

8. "San çıyanı" (Yellow scorpion). The nickname was given by Farida to refer to Comron's character and cold actions, and also to refer to future events. For example:- Ne dedin abla, ne dedin? Ben, sinsi san çıyanı... Müjgân, soluk soluğa kendini kurtarmaya çalışıyor, debeleniyordu (P. 64). - (What did you say, sister, what did you say? I saw that yellow scorpion ... Mujgon was trying to save himself from death and resurrection.)

9. "Ayı Dayı" (Bear wrestler). The nickname was given by the soldiers because of the appearance, shape and behavior of the soldier. For example:Yahu, yüzbaşım, hatırın kalmasın ama sana: "Ayı Dayı" adını takanların yerden göğe kadar hakları varmış (P. 206). - (Hey, Captain, don't be angry, but those who call you "Bear Wrestler" have a right.)

10. "Sarı zalim" (Yellow cruel). Although the nickname was given to the cat in relation to its color, it was actually chosen by the author in connection with Fareda's feelings. For example: Nasıl, kuşu parçalandın mı, sarı zalim? (P. 268). - 
CURRENT RESEARCH JOURNAL OF PHILOLOGICAL SCIENCES 2(7): 05-09,

May 2021 DOI: https://doi.org/10.37547/philological-crjps-02-07-02

ISSN 2767-3758

(C)2021 Master Journals

\section{Crossref do) 8 Google}

Accepted09thJuly, 2021 \& Published 14thJuly, 2021

(So, yellow devil, did you tear the bird apart? I teased.)

11. "Sarı mahluk"(Yellow monster). The nickname was given to Comron because of his appearance and image, and because of Farida's agony. For example: Diye eğleniyordum, içimde derin bir sevinç vardı. Yalnız bu sarı kediden değil, zavallı küçük kuşlara musallat olan bütün sarı mahluklardan öç almış gibi seviniyordum (P. 268). (A deep joy awoke in my heart. I rejoiced not only in this yellow cat, but in all the yellow monsters that did not give a damn about the poor little birds.)

12. "Düldül" (Duldul). The nickname was given by the owner of the horse, which was the most important animal of the time and a dear friend. For example: Hastaneyi bıraktığı günden beri kâh günlerce evine kapanarak kitap okuyor, kâh askerlikten kalma çizmelerini çekiyor, sırtına jandarma gibi bir tüfek takarak Düldül'e biniyor: (düldül, onun pek sevdiği emektar atıdır) bu kıyafetle köylerde bakacak hasta, kendini meşgul edecek bir iş aramaya gidiyor (P. 337). (Sometimes he puts on his military boots, carries a gendarmerie-like rifle on his shoulder and rides on Duldul (Duldul is his favorite horse). He wanders around the villages, looking after the sick, looking for something to feed himself).

13. "Odabaşı" (Captain). The nickname was given to a beloved gardener by his host, a military doctor, Khairullobey. For example: Evinde seksenlik bir sütanne ile "Odabaș" diye çağırdığı topal bir bahçıvan var (P.337). (With an eighty-year-old dairy nurse in his home, he is left with a lame gardener whom he calls a "Captain").

14. "Sevgili ayıcıklarım" (Dear bears). The nickname was given to the soldiers, who were as precious and beloved as their children, by a kind and strict doctor. For example: Öyle anliyorum ki, bu ihtiyar doktor, ne para için ne de bir vazife fikriyle askerlik ediyor, onun bir iptilası var: "Sevgili ayıcıklarım" dediği biçare neferlere muhabbet! (P.326). (As far as I know, this old doctor is serving in the army neither for money nor for military service. He has his own aspiration: this aspiration is his love for the coloring soldiers he calls "my dear bears").

\section{Conclusion}

In conclusion, Rashod Nuri Guntekin conditionally divided the whole system of events in the novel "Cholikushi" into three parts, connecting them with certain paraphrases. These are: "Farida - Cholikushi", "Farida - Silkworm", "Farida - Gulbashakar". Each paraphrase and nickname used by the author is used as a means to convey a specific goal to the reader. the main part of the nicknames are Turkish words, some of which are Persian (gül, dayı) and Arabic (zalim, mahluk) words, only one nickname is French (gourde) which was used to convey the spirit of the time. History has it that the nickname was given to a group of people in Europe who considered themselves nobles at the time because they spoke French.

\section{REFERENCES}

1. Azim Hojiev. Annotated Dictionary of Linguistic Terms. "Tashkent": UZME Publishing House.2002. P. 80.

2. R.Rasulov, I.Umirov. Annotated Dictionary of Paraphrases. Tashkent: "Teacher" Publishing House. 1996. P. 5.

3. Ikhtiyor Umirov. Uzbek language paraphrases. Tashkent: "UzSWLU" Publishing House.2004.

4. R.Rasulov, I.Umirov. Annotated dictionary of figurative expressions of the Uzbek language. Tashkent: "Teacher "Publishing House.1997.

5. A.Rustamov. Word for word. Tashkent:.1987. 
CURRENT RESEARCH JOURNAL OF PHILOLOGICAL SCIENCES 2(7): 05-09,

May 2021 DOI: https://doi.org/10.37547/philological-crjps-02-07-02

ISSN 2767-3758

(C)2021 Master Journals

Crossref do: 81 Google

Accepted09thJuly, 2021 \& Published 14thJuly, 2021

6. D.E.Rozental. Dictionary of linguistic terms. Moscow:,1976.

7. A.Shomaqsudov, I.Rasulov, R.Kungurov, H.Rustamov. Stylistics of the Uzbek language. Tashkent:, 1983.

8. R.Kungurov. Descriptive expressions of the Uzbek language. Tashkent:, 1977.

9. A.T.Rubailo. Artistic means of language. Novgorod:. 1961.

10. R.A. Budagov. Introduction to the science of language. Moscow:.1958.

11. A.M. Efimov. The stylistics of artistic speech. Moscow:.1957.

12. R. Normurodov. Paraphrases in Oybek's work.

13. U. Tursunov, J. Mukhtorov, Sh. Rahmatullaev. Modern Uzbek literary language. Tashkent:,1992.

14. N. Shukurov. Styles and genres. Tashkent:.1973.

A. Shomaksudov. Stylistics of the Uzbek language. Part 2. Tashkent:. 1974.

15. М.Миртожиев. Polysemy in the Uzbek language. Tashkent:.1975.

A. Sodiqov, A. Abduazizov, M. Iriskulov. Introduction to Linguistics. Tashkent:. 1981.

16. Y.Tojiev. Affixal synonymy in Uzbek language. Tashkent:.1991.

17. M. Khairullaev, M. Hakberdiev. Logic (Science of Logic). Tashkent:.1984.

18. H. Nematov, O. Bozorov. Language and speech. Tashkent:.1983.

19. Azim Khojiev. Explanatory dictionary of linguistic terms. Tashkent: "UZME" Publishing House. 2002. P. 80. of Paraphrases. Tashkent: "Teacher" Publishing House. 1996. P. 5.

21. Explanatory dictionary of the Uzbek language. Five years. In the second year. Tashkent: "UZME" Publishing House.2006. P. 492.

22. Lafasov, U. P. (2020). Relationship Between Turks And Japanese. International Journal of Scientific and Technology Research, 9(2), 3935-3938.

23. Lafasov, U. (2021). The Migration of the Japanese from the Center of Turan to the East. Journal of Contemporary Issues in Business and Government, 27(1), 380-388.

24. Rakhmonova, D. N. (2019). DEVELOPMENT OF MUSIC CULTURE FOR ELEMENTARY SCHOOL PUPILS WITH USING INTERACTIVE SOFTWARE. Theoretical \& Applied Science, (12), 101106.

25. SAIDAZIMOVA, U. T. (2021). The issue of two women in the korean art world. Journal of Contemporary Issues in Business and Government, 27(3), 303-308.

20. R.Rasulov, I.Umirov. Annotated Dictionary 